\title{
Modification of the Calcium-Independent Mechanism of Cell Adhesion in Transformed BHK Cells
}

\author{
Hideko Urushihara and Yoji Ikawa \\ Department of Viral Oncology, Cancer Institute, 1-37-1 Kami-ikebukuro, \\ Toshima-ku, Tokyo 170, Japan
}

\begin{abstract}
The calcium-independent mechanism of cell adhesion was studied in normal and polyoma virus-transformed BHK cells. The degree of $\mathrm{Ca}^{2+}$-independent adhesion was greatly reduced in pyBHK cells, whereas $\mathrm{Ca}^{2+}$-dependent adhesion occurred to the same degree as in BHK cells. This decrease was shown not to be caused by simple masking of the adhesion sites or by their altered sensitivity to trypsin.

Adhesion-blocking antibodies were used to identify molecules responsible for $\mathrm{Ca}^{2+}$-independent adhesion. The antibodies precipitated surface molecules specific for adhesion-competent cells. These have tentatively been named CIDS $_{\mathrm{BHK}}$ and CIDS $_{\mathrm{pyBHK}}$. Both were glycoproteins with respective apparent molecular weights of $120 \mathrm{~K}$ and $125 \mathrm{~K}$. CIDS $_{\mathrm{pyBHK}}$ incorporated ${ }^{3} \mathrm{H}$-glucosamine more than $\operatorname{CIDS}_{\mathrm{BH}}$ did. Possible modification of the $\mathrm{Ca}^{2+}$-independent adhesion mechanism in pyBHK cells is discussed.
\end{abstract}

Studies of cell adhesion are of fundamental importance for the analysis of malignancy as well as for understanding animal morphogenesis. Thus, we have been studying adhesion mechanisms in BHK and pyBHK cells $(1,2)$. We previously showed that both cell types possess $\mathrm{Ca}^{2+}$-dependent (CD) and $\mathrm{Ca}^{2+}$-independent (CID) mechanisms for cell adhesion and that the degree of CID aggregation is greatly reduced in pyBHK cells, whereas CD aggregation in these cells occurs as in BHK cells (2).

Ozaki et al. reported that microtubule-assembly is not related to the CID adhesion mechanisms of BHK and pyBHK cells (3). Therefore, we need to know what is the molecular basis for the CID adhesion mechanisms of these cells. There have been several reports published on transformation-related changes in cellular products (4-7), and some are thought to be relevant to cell adhesion. For example, fibronectin is known to be markedly reduced after oncogenic transformation (6). Vinculin, a recently found cytoskeletal component $(8,9)$, is phosphorylated in Rous sarcoma virus (RSV)-transformed cells (7). To our knowledge, however, no alteration of the cell adhesion molecule itself has yet been reported.

The CID mechanism of cell adhesion was studied extensively in our previous research on Chinese hamster V79 cells $(10,11)$. The molecule responsible for the CID aggregation of V79 cells $\left(\right.$ CIDS $_{\mathrm{v}}$ 79) was shown by immunochemistry to be a glycopro-

Abbreviations used: $\mathrm{BHK}, \mathrm{BHK} 21 /$ Clone 13; pyBHK, polyoma virus-transformed BHK; CD, $\mathrm{Ca}^{2+}$-dependent; $\mathrm{CID}, \mathrm{Ca}^{2+}$-independent; CIDS, $\mathrm{Ca}^{2+}$-independent adhesion site; FCS, fetal calf serum; LTE-cells, light trypsin-EDTA treated cells; TE-cells, trypsin-EDTA treated cells; HCMF, Hepes-buffered $\mathrm{Ca}^{2+}$ - and $\mathrm{Mg}^{2+}$-free saline; TBS, Tris-buffered saline. 
tein with an apparent M.W. of 125,000 daltons (11). In the present study reported here, we found that Fab fragments prepared from the antiserum that detected CIDS $_{\mathrm{v} 79}$ inhibited the CID aggregation of BHK and pyBHK cells. Thus, we have tried using this antiserum to identify molecules related to the CID adhesion of these cells.

\section{MATERIALS AND METHODS}

Cells. BHK21 clone 13 (BHK), polyoma virus-transformed BHK (pyBHK) (1) and Chinese hamster V79 cells (12) were used. Cells were grown in Dulbecco's modified Eagle's MEM supplemented with $10 \%$ fetal calf serum (FCS).

Cell Dissociation and Reaggregation. Cells in monolayer cultures were dispersed for the reaggregation experiments as described previously (2). For preparation of cells that had only the CID adhesion mechanisms (LTE-cells), cells were dispersed at $37^{\circ} \mathrm{C}$ for $15 \mathrm{~min}$ with $1 \mu \mathrm{g} / \mathrm{ml}$ crystallized trypsin (Sigma, Type I) in $\mathrm{Ca}^{2+}$ - and $\mathrm{Mg}^{2+}$-free saline buffered with HEPES at pH 7.4 (HCMF) (13) containing $1 \mathrm{mM}$ EDTA. Cells with no adhesion mechanisms (TE-cells) were prepared with $100 \mu \mathrm{g} / \mathrm{ml}$ trypsin in HCMF containing $1 \mathrm{mM}$ EDTA.

Dissociated cells $\left(4 \times 10^{5}\right.$ in $\left.0.5 \mathrm{ml} \mathrm{HCMF}\right)$ were inoculated into one well ( $15 \mathrm{~mm}$ diameter) of a multi-well plate (Falcon 3008) then incubated on a gyratory shaker (New Brunswick, Model G24) at $80 \mathrm{rpm}$ and $37^{\circ} \mathrm{C}$. The degree of aggregation was represented by an aggregation index defined as $\mathrm{N}_{t} / \mathrm{N}_{0}$, in which $\mathrm{N}_{t}$ and $\mathrm{N}_{0}$ are the total number of particles per well at times $t$ and 0 . The degree of inhibition of aggregation by antiserum or enzymes was represented by the inhibition index Iag defined as Iag $=\left[\left(\mathrm{N}_{\mathrm{t}}(\mathrm{c})-\mathrm{N}_{\mathrm{t}}(0)\right) / \mathrm{N}_{0}-\mathrm{N}_{\mathrm{t}}(0)\right] \times 100$ $(\%)$, in which $\mathrm{N}_{t}(\mathrm{c})$ is the total number of particles at incubation time, $t$, in the presence of reagents at concentration, c (11). Negative values of Iag indicate the promotion of aggregation.

Preparation of Antibodies. Preparation of the antisera has been described elsewhere. Anti E-V79 antiserum (10) was obtained from rabbits immunized with whole V79 cells that had been dissociated with EDTA and anti TRF antiserum (11) with trypsin-released fragments from V79 cells. Immunoglobulin G(IgG) and Fab fragments of the above antisera and of normal rabbit serum were prepared as described previously (10).

Radio-labeling of Cell Components. Surface proteins of the cells were labelled with ${ }^{125} \mathrm{I}$ by the lactoperoxidase-mediated method (14). Dispersed cells $\left(1 \times 10^{7}\right)$ were suspended in $2 \mathrm{ml}$ of iodination solution containing $800 \mu \mathrm{Ci} \mathrm{Na}{ }^{125}$ (carrier free, New England Nuclear), $40 \mu \mathrm{g}$ lactoperoxidase (Miles), 0.2 units glucose oxidase (Miles) and $5 \mathrm{mM}$ glucose in HCMF then incubated for $10 \mathrm{~min}$ in an ice bath with occasional shaking.

Polysaccharides of cells were labelled for $24 \mathrm{~h}$ with $50 \mu \mathrm{Ci} / \mathrm{ml}$ of ${ }^{3} \mathrm{H}$-glucosamine $(32.5$ $\mathrm{Ci} / \mathrm{mM}$ ). Cell density was approximately $7 \times 10^{4} / \mathrm{cm}^{2}$ at the start and increased to about $1.5 \times 10^{5} / \mathrm{cm}^{2}$ at the end of labelling.

Immunoprecipitation. Immunoprecipitation was done by modification of Kessler's method with formalin-fixed Staphylococcus aureus (Calbiochem) (15). The bacteria were heat treated then incubated with $10 \mu \mathrm{l}$ of rabbit antiserum in a total volume of $1 \mathrm{ml}$ of TBS $(10 \mathrm{mM}$ Tris- $\mathrm{HCl} \mathrm{pH} 7.8$ containing $0.15 \mathrm{M} \mathrm{NaCl}$ ) in an ice bath for $30 \mathrm{~min}$. Thie antiserum-bacteria complex was centrifuged at $3,000 \times g$ for $5 \mathrm{~min}$ then suspended in $100 \mu \mathrm{l}$ TBS. Radio-labelled cells were made soluble with $1 \mathrm{ml}$ of detergent buffer containing $1 \%$ Triton X-100 and $0.1 \%$ deoxycholate in TBS by incubating them at room temperature for $30 \mathrm{~min}$. Insoluble material was removed by centrifugation at $15,000 \times g$ for $20 \mathrm{~min}$. S. aureus, treated as above was added to the lysate, then the mixture was incubated in an ice bath for $30 \mathrm{~min}$. After incubation, the bacteria were washed several times with TBS. Antigens were released by boiling the adsorb- 
ents in the SDS sample buffer used for electrophoresis for $3 \mathrm{~min}$.

Electrophoresis and Autoradiography. SDS-polyacrylamide gel electrophoresis was done according to the method of Laemmli (16), after which the gels were fixed and stained with Vesterbeg's stain ( $450 \mathrm{ml}$ methanol, $1.5 \mathrm{~g}$ Coomasie brilliant blue, $180 \mathrm{~g}$ TCA, $54 \mathrm{~g}$ sulfosalicylic acid and 1.1 liters $\mathrm{H}_{2} \mathrm{O}$ ) for several hours at room temperature.

After destaining, gels with ${ }^{3} \mathrm{H}$-lebelled samples were impregnated with an autoradiography enhancer (EN ${ }^{3}$ HANCE, New England Nuclear) then soaked in water, after which they were dried and exposed to X-ray film (XAR-5, Kodak). Gels with ${ }^{125}$ I-labelled samples were autoradiographed with the same X-ray film.

\section{RESULTS}

Properties of the CID Aggregation of BHK and pyBHK Cells.

(1) Aggregation kinetics. Typical curves for the aggregation kinetics of LTE-BHK and LTE-pyBHK cells are shown in Fig. 1. Aggregation of the latter cells is always less than that of the former, and aggregations of both cell types are $\mathrm{Ca}^{2+}$-independent. Promotion by $\mathrm{Ca}^{2+}$ in the aggregation medium after $1 \mathrm{~h}$ of incubation is due to the recovery of the $\mathrm{CD}$ mechanism because cycloheximide inhibited this promotion.

(2) Trypsin sensitivity. To check the possibility that the decreased aggregating ability of pyBHK cells is caused by differences in the trypsin sensitivity of the adhesion mechanisms in those cells, we treated cell monolayers with various concentrations of trypsin in the presence of EDTA then reaggregated the dispersed cells. The degree of the CID aggregation of pyBHK cells was always less than that o fthe BHK cells throughout the range examined (Fig. 2). Trypsin treatment at concentrations of less than $1 \mu \mathrm{g} / \mathrm{ml}$ somewhat increased the aggregating ability of both cell types. Above this concentration the adhesiveness of the cells decreased with the increase in trypsin concentration and on trypsinization at $100 \mu \mathrm{g} / \mathrm{ml}$ cells became almost non-adhesive. Fifty percent inhibition was achieved ca. $50 \mu \mathrm{g} / \mathrm{ml}$ trypsin for both BHK and pyBHK cells. LTE-cells are represented by (a) and TE-cells by (b) in Fig. 2.

(3) Inhibition of aggregation by anti E-V79 Fab. Anti E-V79 Fab inhibited the aggregation of LTE-BHK and LTE-pyBHK cells as well as that of LTE-V79 cells

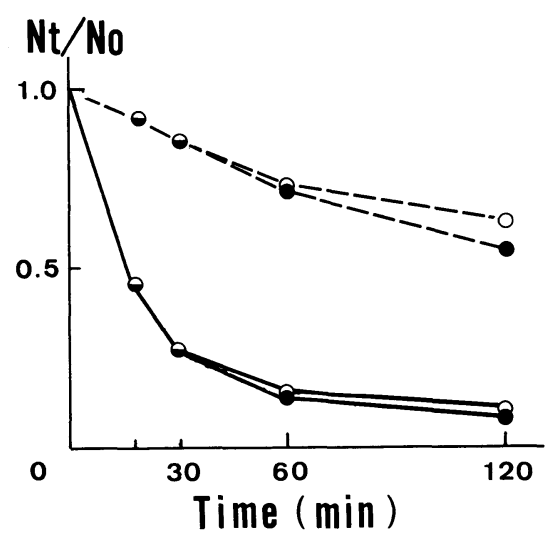

Fig. 1. Aggregation kinetics of LTE-BHK and LTE-pyBHK cells. LTE-BHK ( $\longrightarrow$ ) and LTE-pyBHK cells (--) were aggregated in the presence $(\bullet)$ and absence $(\bigcirc)$ of $1 \mathrm{mM} \mathrm{Ca}^{2+}$ in the aggregation medium. 


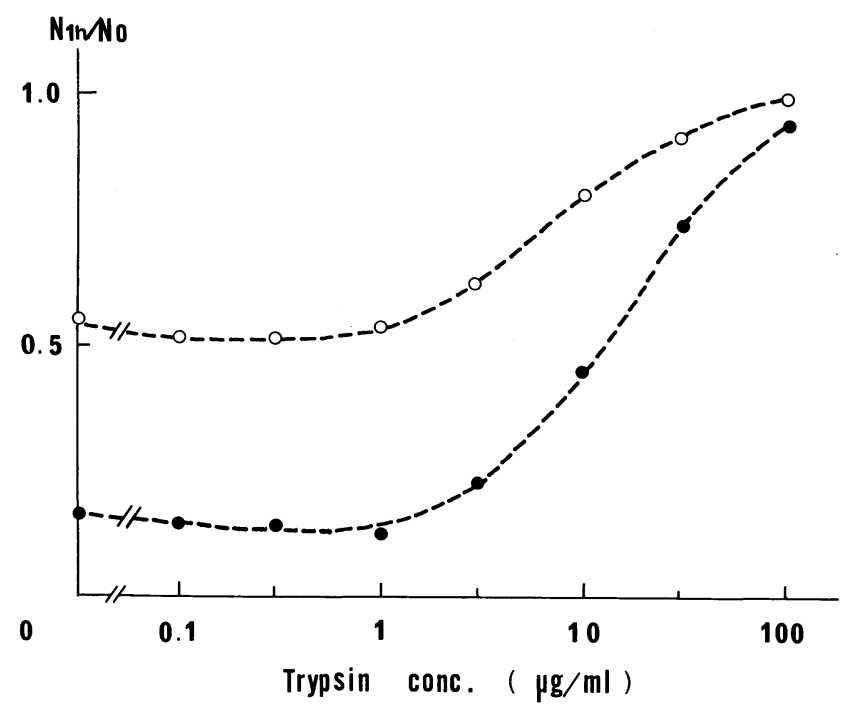

Fig. 2. Trypsin sensitivity of $\mathrm{Ca}^{2+}$-independent adhesion in BHK and pyBHK cells. BHK (๑) and pyBHK $(\bigcirc)$ cells were dispersed by incubation with trypsin, at the concentrations indicated on the abscissa, in the presence of $1 \mathrm{mM}$ EDTA at $37^{\circ} \mathrm{C}$ for $15 \mathrm{~min}$. They then were aggregated in HCMF for $1 \mathrm{~h}$. The degree of aggregation is indicated by the aggregation index defined in the text.

(Table 1). Aggregation of these cells was inhibited completely at high concentrations $(2 \mathrm{mg} / \mathrm{ml})$ of Fab. As judged by the Fab concentrations needed for $50 \%$ inhibition, anti E-V79 Fab was least effective on BHK cells. Fab from normal rabbit serum promoted, rather than inhibited, the aggregation of all the cells, the Iag being around $-5 \%$. Anti-TRF Fab inhibited neither the aggregation of LTE-BHK nor LTEpyBHK cells.

(4) Effect of hyaluronidase. Because hyaluronidase synergistically inhibited the aggregation of LTE-V79 cells with anti-TRF Fab (11), we examined the involvement of hyaluronic residues in the CID aggregation of BHK and pyBHK cells by treating LTE-cells with hyaluronidase from Streptomyces hyalurolyticus (Seikagaku Kogyo, Japan). The aggregation of hyaluronidase-treated LTE-cells is shown in Table 2. The enzyme had opposite effects on LTE-BHK and LTE-pyBHK cells. The former cells became slightly less adhesive on enzyme treatment, whereas LTE-pyBHK cells cells became more adhesive, but the degree of aggregation for pyBHK cells was lower than that for BHK cells even after the most effective treatment.

TABLE 1. INHIBITION OF AGgREgATION BY ANTI E-V79 FAB

\begin{tabular}{|c|c|c|c|c|}
\hline \multirow{2}{*}{ Cell } & \multicolumn{3}{|c|}{ Inhibition $^{a}$ by Fab at } & \multirow{2}{*}{$\begin{array}{c}\text { Fab concentration } \\
\text { for } \\
50 \% \text { inhibition }\end{array}$} \\
\hline & $0.1 \mathrm{mg} / \mathrm{ml}$ & $0.2 \mathrm{mg} / \mathrm{ml}$ & $2 \mathrm{mg} / \mathrm{ml}$ & \\
\hline LTE-BHK & 19.2 & 64.6 & 100 & $0.16 \mathrm{mg} / \mathrm{ml}$ \\
\hline LTE-pyBHK & 29.2 & 83.7 & 100 & 0.11 \\
\hline LTE-V79 & 45.8 & 66.7 & 100 & 0.11 \\
\hline
\end{tabular}

LTE-cells were aggregated in the presence and absence of anti E-V79 Fab for $1 \mathrm{~h}$, then the inhibition index (Iag) was calculated.

a Indicated as the $\operatorname{Iag}(\%)$ defined in the text. 
TABLE 2. EFFECT OF HYALURONIDASE TREATMENT ON AGGREGATION OF LTE-BHK AND LTE-PYBHK CELLS

\begin{tabular}{|c|c|c|c|c|}
\hline \multirow{2}{*}{$\begin{array}{c}\text { Hyaluronidase } \\
\text { concentration } \\
(\mathrm{U} / \mathrm{ml})\end{array}$} & \multicolumn{2}{|c|}{ LTE-BHK } & \multicolumn{2}{|c|}{ LTE-pyBHK } \\
\hline & $\begin{array}{c}\text { Aggregation } \\
\left(\mathrm{N}_{1 \mathrm{~h}} / \mathrm{N}_{0}\right)\end{array}$ & $\begin{array}{c}\text { Inhibition } \\
(\operatorname{Iag}(\%))\end{array}$ & $\begin{array}{c}\text { Aggregation } \\
\left(\mathrm{N}_{1 \mathrm{~h}} / \mathrm{N}_{0}\right)\end{array}$ & $\begin{array}{c}\text { Inhibition } \\
(\operatorname{Iag}(\%))\end{array}$ \\
\hline $0^{\mathrm{a}}$ & .149 & 0 & .547 & 0 \\
\hline 20 & .168 & 2.2 & .486 & -13.5 \\
\hline 40 & .183 & 4.0 & .444 & -22.7 \\
\hline 80 & .214 & 7.6 & .466 & -17.9 \\
\hline 100 & .196 & 5.5 & .450 & -21.4 \\
\hline No treatment $t^{b}$ & .096 & $\ldots$ & .505 & - \\
\hline
\end{tabular}

LTE-BHK and LTE-pyBHK cells were treated with hyaluronidase and reaggregated for $1 \mathrm{~h}$. For the enzyme treatment, $3 \times 10^{6}$ cells were incubated with appropriate concentrations of hyaluronidase in $0.5 \mathrm{ml} \mathrm{HCMF}, \mathrm{pH} 6.6$, at $36^{\circ} \mathrm{C}$ for $60 \mathrm{~min}$ with vigorous shaking. For explanation of aggregation and inhibition indices, see text.

a LTE-cells were incubated without hyaluronidase at $37^{\circ} \mathrm{C}$ for $1 \mathrm{~h}$.

b LTE-cells were reaggregated for $1 \mathrm{~h}$ without incubation with or without hyaluronidase.

Immunoprecipitation of Adhesion Molecules. For the identification of molecules related to the CID adhesion of BHK and pyBHK cells, LTE- and TE-cells were prepared from BHK, pyBHK and V79 cells, and their surface proteins were radioiodinated. Lysates of the labelled cells were immunoprecipitated with anti E-V79 antiserum and these precipitates were analyzed by SDS-polyacrylamide gel electrophoresis followed by autoradiography. Several bands were detected in each lane of the autoradiograms (Fig. 3), but a comparison of the LTE- and TE-cells of each cell type showed that only one band predominates in the LTE-cells (asterisks in Fig. 3(A) and (B)). The LTE-specific band in V79 cells coincides with the position of CIDS ${ }_{\mathrm{v} 79}$

(A)

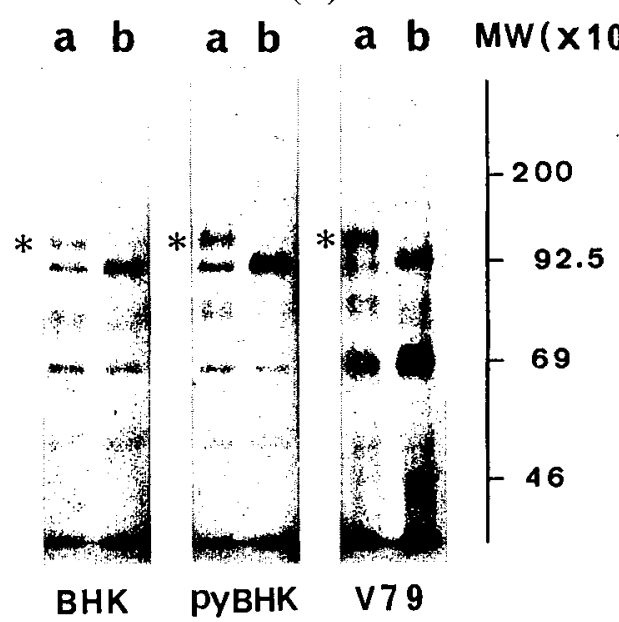

(B)

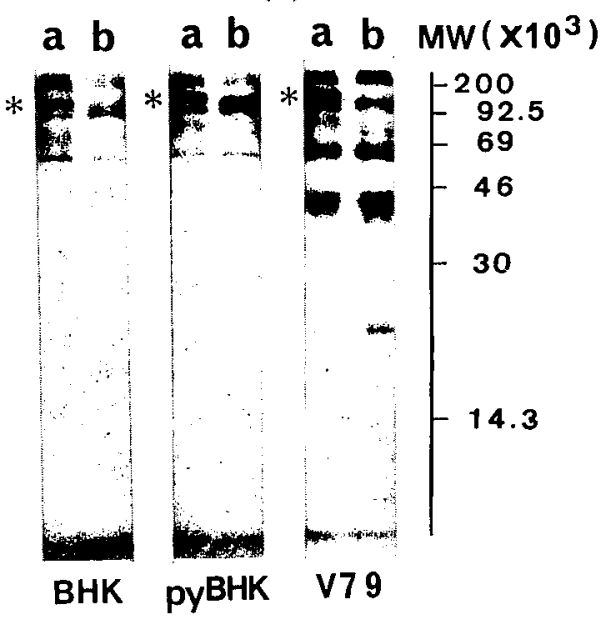

Fig. 3. Immunochemical detection of CIDS's in BHK, pyBHK and V79 cells. Radio-iodinated LTE-(a) and TE-cells (b) were lysed and immunoprecipitated with anti E-V79 antiserum. The immunoprecipitates were separated by SDS-polyacrylamide gel electrophoresis. Autoradiograms of $7.5 \%$ (A) and $15 \%$ (B) gels are shown. Asterisks show bands specific for LTE-cell precipitates. 


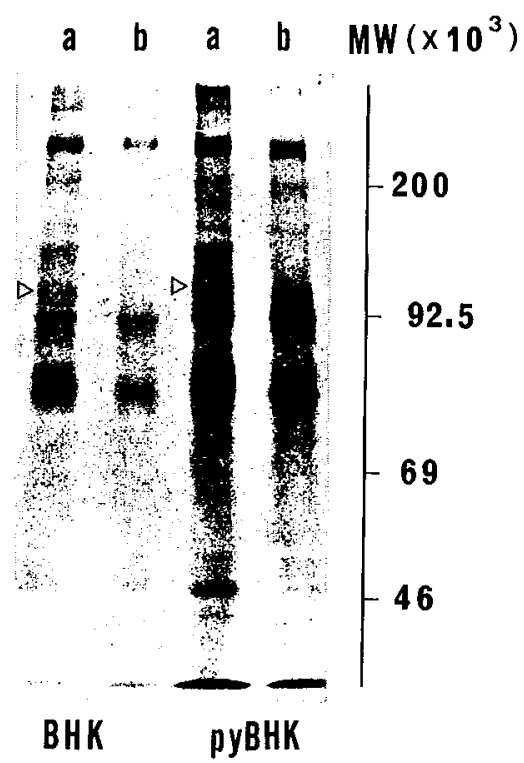

Fig. 4. Fluorogram showing the presence of sugars in CIDS's LTE- (a) and TE-cells (b) were prepared from ${ }^{3} \mathrm{H}$-glucosamine-labelled $\mathrm{BHK}$ and pyBHK cells then lysed and immunoprecipitated with anti E-V79 antiserum. Bands indicated by the arrowheads correspond to CIDS $_{\mathrm{BHK}}$ and CIDS $_{\text {pyBHK. }}$

detected with anti TRF. These LTE-cell specific bands probably represent CID adhesion molecules as they exist on the surface of CID adhesion-competent cells but not on adhesion-incompetent cells, and they react with adhesion-blocking antibodies. These bands have tentatively been named CIDS $_{\text {вн }}$ and CIDS $_{\text {рувнк. Some bands }}$ also are specific to TE-cells. They probably represent inactivated forms of CIDS's.

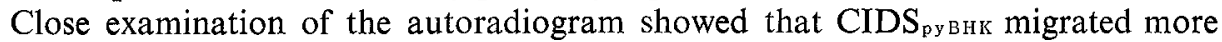

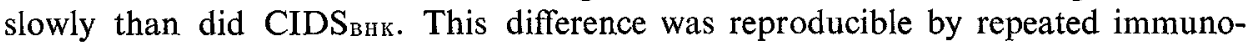
precipitation. The molecular weights were estimated as ca. $120 \mathrm{~K}$ for $\mathrm{CIDS}_{\mathrm{BHK}}$ and

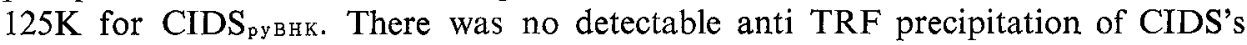
in BHK and pyBHK cells.

${ }^{3}$ H-glucosamine Labelling of CIDS's. When LTE-BHK and LTE-pyBHK cells were prepared from ${ }^{3} \mathrm{H}$-glucosamine-labelled cells and their lysates were immunoprecipitated with anti E-V79 antiserum, components with molecular weights corresponding to those of $\operatorname{CIDS}_{\mathrm{BHK}}$ and $\mathrm{CIDS}_{\mathrm{pyBHK}}$ were detected on a fluorogram (arrowheads, Fig. 4). Both types of components were absent from precipitates of TE-BHK and TE-pyBHK cells. There were some other bands developed less intensively in TE-cells than in LTE-cells in both the BHK and pyBHK cells. Although the conditions for radiolabelling, immunoprecipitation and electrophoresis were exactly the same for all four types of cells, the radioactivity of samples from pyBHK cells was higher than that from BHK cells. Differences between the two cell types are summarized in Table 3.

\section{DISCUSSION}

Our previous research has shown that there are $\mathrm{Ca}^{2+}$-dependent $(\mathrm{CD})$ and $\mathrm{Ca}^{2+}$ - 
TABLE 3. INCORPORATION OF RADIOACTIVITY TO BHK AND PYBHK CELLS METABOLICALLY LABELLED WITH ${ }^{3} \mathrm{H}$-GLUCOSAMINE

\begin{tabular}{lcccccc}
\hline & \multicolumn{2}{c}{ BHK } & & \multicolumn{2}{c}{ pyBHK } \\
\cline { 2 - 3 } \cline { 5 - 6 } & \multicolumn{2}{c}{ LTE } & TE & LTE & TE \\
\hline Whole cell lysate & $1.67 \times 10^{7}$ & $1.18 \times 10^{7}$ & & $3.00 \times 10^{7}$ & $2.70 \times 10^{7}$ \\
Whole precipitate & $1.3 \times 10^{4}$ & $0.9 \times 10^{4}$ & & $5.0 \times 10^{4}$ & $2.5 \times 10^{4}$ \\
CIDS & $13 \times 10^{2}$ & $0.4 \times 10^{2}$ & & $24 \times 10^{2}$ & $1.8 \times 10^{2}$ \\
CIDS/TOTAL & $8.1 \times 10^{-5}$ & $0.4 \times 10^{-5}$ & & $7.9 \times 10^{-5}$ & $0.7 \times 10^{-5}$ \\
$\quad$ incorporation & & & & &
\end{tabular}

One million cells were cultured in the presence of $50 \mu \mathrm{Ci} / \mathrm{ml}{ }^{3} \mathrm{H}$-glucosamine for $24 \mathrm{~h}$. LTE- and TE-cells were prepared from these labelled cells, then lysed and immunoprecipitated with anti E-V79 antiserum, after which they were electrophoresed. Samples of cell lysates and precipitates were used to measure radioactivities of the whole cell lysates and of the total precipitates. For measurement of the radioactivity of CIDS's, the gel was superimposed on its fluorogram and corresponding regions of the gel were cut out. All radioactivities shown were adjusted to $2 \times 10^{6}$ cells.

independent (CID) mechanisms for cell-to-cell adhesion in BHK and pyBHK cells and that the degree of CID adhesion is much less in pyBHK cells than in their normal counterparts (2). The results described above suggest that this decrease is caused by an alteration(s) in the adhesion molecule itself rather than being caused by different trypsin sensitivity or simple masking of adhesion sites by proteinaceous substances.

To identify the molecules responsible for the CID aggregation of BHK and pyBHK cells, we used anti E-V79 antiserum, an antiserum originally raised for the study of adhesion molecules in Chinese hamster V79 cells (10). This use was based on the fact that the CIDS's in various cells can cross-react to a degree (17). In fact, Fab fragments prepared from anti E-V79 antiserum inhibited the aggregation of LTE-BHK and LTE-pyBHK cells. Among the target molecules of the anti E-V79 antibodies we detected surface molecules specific to LTE-BHK or to LTE-pyBHK cells. These we

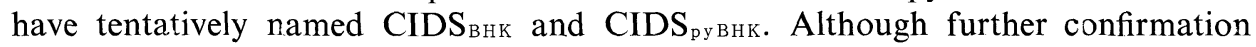
is necessary, these probably are adhesion molecules because they are the only molecules found that satisfy the characteristics of adhesion molecules. i.e., $\mathrm{CIDS}_{\mathrm{BHK}}$ and CIDS $_{\mathrm{py} \mathrm{Bнк}}$ exist on the surface of CID-adhesion competent cells (LTE-cells) but not on the surface of CID-adhesion incompetent cells (TE-cells), and they react with adhesion-blocking antibodies.

The detection of CIDS $_{\mathrm{BHK}}$ and CIDS $_{\mathrm{py} \mathrm{внк}}$ revealed a striking similarity among the CIDS's of BHK, pyBHK and V79 cells. All are glycoproteins with apparent molecular weights of ca. 120,000 daltons and are immunologically cross-reactive. Detailes of their natures, however, differ. CIDS $_{\text {внк }}$ and CIDS $_{\mathrm{py} \mathrm{внк}}$ did not react with anti TRF antibodies in either the inhibition-of-aggregation assay or in immunoprecipitation. This probably was because the antiserum mainly detects antigenic determinants specific for Chinese hamster cells. This phenomenon is interesting because of the generality and specificity of the CID mechanism of cell adhesion in different cell types.

The molecular weights of CIDS $_{\mathrm{BHK}}$ and CIDS $_{\mathrm{pyBHK}}$ are very close, but the weight of the latter is slightly larger. Although there was no quantitative difference between iodinated CIDS $_{\mathrm{HBK}}$ and $\mathrm{CIDS}_{\mathrm{pyBHK}}$ that would explain the decreased adhesiveness of pyBHK cells, the incorporation of ${ }^{3} \mathrm{H}$-glucosamine differed markedly. As increased 
incorporation into pyBHK cells is not solely a phenomenon of CIDS $_{\mathrm{py} \mathrm{BHK}}$ but is common to the components of all the pyBHK cells, it seems to confirm other findings that sugar chains in transformed cells are generally larger than their normal counterparts (18). Overglycosylation of cellular constituents can be assumed to be reflected in the larger molecular wieght of CIDS pyBHK and to be the cause of the decrease in its ability to bind cells. This assumption could explain why hyaluronidase treatment of LTE-pyBHK cells partially restored the aggregating ability of pyBHK cells.

Recent findings have shown that a product of the $s r c$ gene of RSV, (pp60 ${ }^{\text {src }}$ ), is associated with protein kinase activity $(19,20)$ and that many products in RSVtransformed cells are phosphorylated (21). Similar alterations in enzymatic activities have been found in other transformed cells (22). Thus, we need to determine the relationship between the expression of polyoma T-antigens (23) and the modification of adhesion molecules in pyBHK cells. Further studies are necessary to show by what mechanism adhesion molecules are altered during the malignant transformation of cells.

Acknowledgement. We are grateful to Dr. T. Atsumi for valuable comments on the research reported and his critical reading of the manuscript. H. Urushihara is the recipient of the Postdoctoral Fellowship from the Japan Society for Promotion of Science.

\section{REFERENCES}

1. Urushihara, H., M. Takeichi, A. Hakura and T.S. Okada. Different cation requirements for aggregation of BHK cells and their transformed derivatives. J. Cell Sci. 22, 685-695, 1976

2. Urushihara, H., M.J. Ueda, T.S. OKada and M. Takeichi. Calcium-dependent and -independent adhesion of normal and transformed BHK cells. Cell Struct. Funct. 2, 289-296, 1977

3. Ozaki, H.S., T.S. OKada and K. Yasuda. Does colchicine affect aggregation of normal and transformed BHK cells differently? Develop. Growth and Differ. 20, 55-60, 1978

4. Deleo, A.B., G. JAY, E. Appella, G.C. Dubois, L.W. LaW and L.J. Old. Detection of a transformation-related antigen in chemically induced sarcomas and other transformed cells of the mouse. Proc. Natl. Acad. Sci. U.S.A. 76, 2420-2424, 1979

5. Brzeski, H. and T. EgE. Changes in polypeptide pattern in ASV-transformed rat cells are correlated with the degree of morphological transformation. Cell 22, 513-522, 1980

6. Hynes, R.O. Cell surface proteins and malignant transformation. Biochim. Biophys. Acta. 458 73-107, 1976

7. Sefton, B.M. and T. Hunter. Vinculin: A cytoskeletal target of the transforming protein of Rous sarcoma virus. Cell 24, 165-174, 1981

8. GeIGER, B. A $130 \mathrm{~K}$ protein from chicken gizzard: Its localization at the termini of microfilament bundles in cultured chicken cells. Cell 18, 193-205, 1979

9. Geiger, B., K.T. Tokuyasu, A.H. Dutton and S.J. Singer. Vinculin, an intracellular protein localized at specialized sites where microfilament bundles terminate at cell membranes. Proc. Natl. Acad. Sci. U.S.A. 77, 4127-4131, 1980

10. Urushihara, H., H.S. OzaKi and M. TAKeIChi. Immunological detection of cell surface components related with aggregation of Chinese hamster and chick embryonic cells. Dev. Biol. 70, 206-219, 1979

11. Urushihara, H. and M. Takeichi. Cell-cell adhesion molecule: Identification of a glycoprotein relevant to the $\mathrm{Ca}^{2+}$-independent aggregation of chinese hamster fibroblasts. Cell 20, 363-371, 1980

12. YU, C.K. Evaluation and nature of the near-diploid cells of Chinese hamster (Cricetulus griseus) in vitro. Canad. J. Genet. Cytol. 5, 307-317, 1963

13. TAKeICHI, M. Functional correlation between cell adhesive properties and some cell surface proteins. J. Cell Biol. 75, 464-474, 1977 
14. Hubbard, A.L. and Z.A. Cohn. The enzymatic iodination of the red cell membrane. J. Cell Biol. 55, 390-405, 1972

15. Richert, N.D., P.J.A. Davies, G. JAY and I.H. PAStan. Characterization of an immune complex kinase in immunoprecipitates of avian sarcoma virus-transformed fibrolasts. J. Virol. 31, 695-706, 1979

16. Laemml, U.K. Cleavage of structural proteins during the assembly of the head of Bacteriophage T4. Nature 227, 680-685, 1970

17. TaKeichi, M., H.S. OzaKi, K. TokUnaga and T.S. OKada. Experimental manipulation of cell surface to affect cellular recognition mechanisms. Dev. Biol. 70, 195-205, 1979

18. Nicolson, G.L. Trans-membrane control of the receptors on normal and tumor cells. II. Surface changes associated with transformation and malignancy. Biochim. Biophys. Acta 458, 1-72, 1976

19. Collett, M.S. and R.L. Erikson. Protein kinase activity assocated with the avian sarcoma virus src gene product. Proc. Natl. Acad. Sci. U.S.A. 75, 2021-2024, 1978

20. Levinson, A.D., H. Oppermann, L. Levinton, H.E. Varmus and J.M. Bishop. Evidence that the transforming gene of avian sarcoma virus encodes a protein kinase associated with a phosphoprotein. Cell 15, 561-572, 1978

21. Rodke, K. and G.S. Martin. Transformation by Rous sarcoma virus: Effects of src gene expression on the synthesis and phosphorylation of cellular polypeptides. Proc. Natl. Acad. Sci. U.S.A. 76, 5212-5216, 1979

22. Jay, G., G. Khoury, A.B. DeLeo, W.G. Dippold and L.J. Old. p 53 transformation-related protein: Detection of an associated phosphotransferase activity. Proc. Natl. Acad. Sci. U.S.A. 78, 2932-2936, 1981

23. Ito, Y., N. SpUn and B.E. Griffin. Middle T antigen as primary inducer of full expression of the phenotype of transformation by polyoma virus. J. Virol. 35, 219-232, 1980

(Received for publication, February 15, 1983) 